\title{
Besinning oor filosofie in die mistieke kloosterteks Hortus deliciarum (ca. 1185) deur Herrada Landsbergensis (ca. 1130-1191)
}

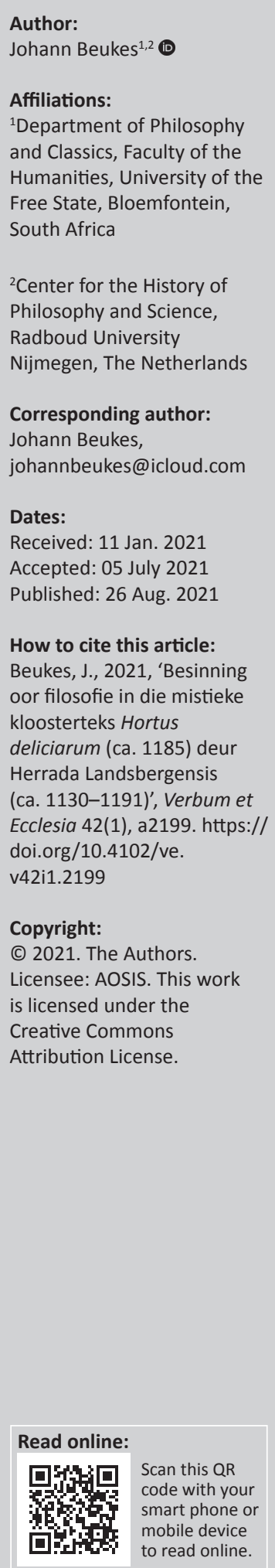

Reflection on philosophy in the mystical cloistral text Hortus deliciarum (ca. 1185) by Herrada Landsbergensis (ca. 1130-1191). The aim of this article is to reappraise the understated philosophical aspects in the mystical cloistral text Hortus deliciarum, finalised around 1185 by Herrada Landsbergensis (ca. 1130-1191; also Herrad of Hohenburg), the abbess at Mont SaintOdile, with specific reference to reflection on the nature and the limits of philosophy. Drawing on the most recent specialist research regarding its historical artistic and theological contributions (per Fiona Griffiths, Danielle Joyner and Nathaniel Campbell), and situating Herrada within a clear Platonic Augustinian framework, her life and the unique aesthetic appeal of the Hortus deliciarum are explored in this article. The reconstructed manuscript (under guidance of Rosalie Green in 1979) is henceforth engaged with, regarding its philosophical selfreflection (on the 'nine Muses' and 'Lady Philosophy and the seven allegorical figures of the liberal arts', as its entrance points), as well as Herrada's modest participation in the intellectual discourse of the twelfth century, regarding cosmology ('the human being as microcosm') and ethics ('both a contemplative and speculative distinction of the good'). Herrada's self-reflective and aesthetic presentation of philosophy and her deeply conservative reflections and emphasis on the didactic nature of philosophy are described as a unique offering from philosophy in the central Middle Ages to the broader landscape of the Western history of ideas.

Intra/interdisciplinary implications: As a millennium-long discourse, Medieval philosophy functions in a Venn diagrammatic relationship with Medieval history, Church history, patristics and the philosophy of religion. Whenever 'mainstream' or 'canonised' Medieval philosophy is impacted by niche research, it may well have implications of which these closely related disciplines could take note. Such is the case in this reappraisal of the philosophical aspects in the Hortus deliciarum by the abbess of Hohenburg, Herrada Landsbergensis.

Keywords: Augustinian Medieval philosophy; Cloistral mysticism; Rosalie Green; Fiona J. Griffiths; Herrada Landsbergensis (ca. 1139-1191); Herrad of Landsberg; Herrad of Hohenburg; Hohenburg Abbey; Hortus deliciarum (ca. 1185); Female Medieval philosophers.

\section{Herrada se plek in die sentrale Middeleeuse ideëgeskiedenis}

Die oogmerk van hierdie artikel is om die mistieke kloosterteks Hortus deliciarum, gefinaliseer rondom 1185 deur Herrada Landsbergensis (ca. 1130-1191), abdis van die Augustynse klooster by Hohenburg (Mont Sainte-Odile) in die ooste van Frankryk, oorspronklik te herlees en die onderbeklemtoonde aspek van filosofiese selfbesinning daarin saaklik uit te lig en te kommentarieer. ${ }^{1}$ Die artikel lewer hiermee 'n bydrae tot die eietydse ontsluiting van die filosofiese uitsette van vroulike Middeleeuse denkers as steeds oorwegend gemarginaliseerde figure in die Westerse ideëgeskiedenis. Buiten filosofiese selfbesinning, lewer die Hortus deliciarum 'n gestroopte, maar aanduibare bydrae tot kosmologie ('die mens as mikrokosmos') en etiek ('om die goeie kontemplatief, sowel as spekulatief te onderskei'). Gemeet aan die skolastiese

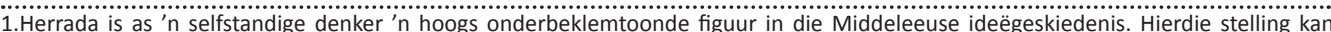
gestaaf word deur daarop te wys dat selfs vanuit die mees onlangse inleidingsnavorsing geen verwysing na Herrada of na die Hortus deliciarum bestaan nie: Beukes (2020a) se inleidingswerk in twee volumes; die omvangryke inleiding en bloemlesing van Bosley en Tweedale (eds. 2004), die filosofiese woordeboek van Brown en Flores (2007); Copleston (1993) se gevierde inleiding; die omvangryke redaksiewerk van Gracia en Noone (eds. 2006); Grant (2004); Hannam (2009); Hyman, Walsh en Williams (eds. 2010); Kenny (2005); Koterski (2009) en Kretzmann, Kenny en Pinborg (1982). Ook die uiters omvangryke ensiklopedie van Lagerlund (ed. 2011), bevat geen verwysing nie, terwyl Luscombe (1997) en ook nie een van Marenbon se twee omvattende oorsigwerke en redaksiewerk (1991, ed. 1998, 2007) 'n verwysing bevat nie. Dieselfde geld vir Martin (1996) en McGrade (2003) se oorsigwerke. In beide volumes van Pasnau en Van Dyke ([eds.] 2010a, 2010b) se magistrale inleidingswerk ontbreek enige verwysing na Herrada Landsbergensis of na die Hortus deliciarum. ' $n$ Toeganklike bywerking van die mees onlangse spesialisnavorsing en die heroorweging van die filosofiese bydraes vanuit die Hortus deliciarum, veral ten opsigte van filosofiese selfbesinning, is teen hierdie agtergrond geregverdig en selfs noodsaaklik. 
multivolume-uitsette vanaf die $12 \mathrm{de}$ eeu, was die filosofiese inhoud van die Hortus deliciarum beskeie - maar nietemin substansieel genoeg om dit saaklik te kan isoleer en herwaardeer.

Herrada Landsbergensis (eers in die 20ste eeu meer algemeen 'Herrada of Hohenburg' genoem²), gebore vanuit 'n aristokratiese familie (von Landsberg) rondom 1130, volg Rilinda, voormalige abdis van Bergen en die herboude klooster by Hohenburg (gestig in 690 deur die eerste abdis, Odile; vandaar die vroeëre pleknaam 'Mont Sainte-Odile'; herbou en herstig in 1147), rondom 1176 op. Sy was waarskynlik deel van die eerste groep van agt leerlinge wat deur Rilinda tussen 1147 en 1162 onder die Ordereëls van Augustinus opgevoed en as nonne georden is (Eckenstein 2010:238). Die klooster het onder Herrada se leiding ontwikkel tot 'n gerespekteerde landmerk wat uiteindelik buiten die kloostergebou ook 'n plaas, 'n kerkgebou, 'n siekeboeg en 'n gastehuis vir pelgrims ingesluit het. Met Herrada se dood in 1191 het meer as 60 nonne permanent in die klooster gewoon (Bischoff 1979:11-12).

Rondom 1185 finaliseer abdis Herrada vanuit hierdie klooster 'n uitgebreide manuskrip of florilegium met die titel Hortus deliciarum (Tuin van verrukkinge, verwysende na die tuin van Eden $^{3}$ en die 'toegemaakte tuin' in Hooglied 4:12), bestaande uit meer as 'n duisend teksverwysings (Bybeltekste, aanhalings uit patristiese tekste en tydgenootlike poësie, bladmusiek, lirieke en diagramme vanuit die 12de eeu) en 340 miniatuursketse, asook volblad-illustrasies in aangrypende detail wat meer as 320 folio's of manuskripbladsye bestryk.

Herrada se teologiese oogmerk met hierdie estetiese aanbod was om ' $n$ interpretasie van geskiedenis as juis heilsgeskiedenis te verskaf, waarin die ontstaan en einde van alle dinge geweeg word vanuit skeppingsleer, sondeleer, verlossingsleer en eskatologie (Campbell 2015:85). Die tuinmotief in Hortus deliciarum (van hier af: 'die Hortus') korrespondeer met haar Duitse tydgenoot Hildegard von Bingen (1098-1179) se voorkeurbegrip viriditas ('groenheid'), waaraan Hildegard die konnotasies van lewegewing, vitaliteit, oorvloed, vrugbaarheid

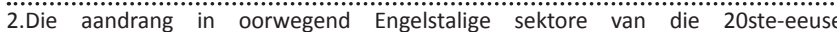
spesialisnavorsing om enige verwysing na Herrada se adellike afkoms ('Landsbergensis') te laat vaar en uitsluitlik volgens pleknaam na 'Hohenborg' te verwys, vind ek nie oortuigend nie. Die verband tussen Herrada en die WesEuropese adelstand word naamlik aan 'n elitistiese en retrospektiewe aanwysing vapuit dic 16de vanuit die 16de eeu toegeskryf (vgl. Kaufmann 1982:172). Die gevolglike aandrang om uitsluitlik na 'Herrad of Hohenburg' te moet verwys, val my as kosmeties op aangesien abdisse volgens gangbare Benediktynse voorskrifte uit die adelstan afkomstig moes gewees het (vgl. Beukes 2019a:71). Hoewel ek kontra-elitisme in di filosofiese sin andersins ondersteun, val so 'n terugwerkende korreksie op die oorspronklike eienaam anachronisties op. Die 12de-eeuse akademiese lewe was in die kerk en samelewing immers onherroeplik hiërargies, indien nie 'elitisties' nie. Herrada was hoogs waarskynlik minstens vanaf die $12 \mathrm{de}$ tot die $15 \mathrm{de}$ eeue as 'Landsbergensis' bekend. Hoe aanvegbaar dit vanuit 'n 20ste-eeuse en kontraelitistiese perspektief dalk ook kan aandoen, handhaaf ek daarom die voornaam en van soos wat dit in die grootse deel van die resepsiegeskiedenis van die Hortus voo die 20ste eeu aangebied is, te wete 'Herrada Landsbergensis'.

3.Die titel van Hortus deliciarum is myns insiens moontlik meer spesifiek ontleen aan Boek XIV (De terra et partibus) Afdeling iii (De Asia) in die Etymologiae van Isidorus van Sevilla (ca. 560-636): "Paradisus" est locus in orientis partibus constitutus, cujus vocabulum ex Graeco in Latinum veritur "hortus"; porro Hebraice Eden dicitur, quod in nostra lingua deliciae interpretatur. Quod utrumque junctum facit "hortum deliciarum"'. (Skrywer se semantiese vertaling: "Die "paradys" is 'n plek gesetel in die Ooste, waarvan die naam, vertaal vanuit Grieks na Latyn is "hortus", 'n tuin. In Hebreeus word dit Eden genoem, wat in Latyn deliciae, verrukkinge, beteken. Saamgebring, bied dit hortus deliciarum aan, "die tuin van verrukkinge"'); vergelyk Saamgebring, bied dit hortus deliciarum aan, "die tuin van verrukkinge"'); vergelyk
ook Barney et al. (2006:285) se meer sintaktiese vertaling van die passasie in Engels. en 'n sin vir dinamiese welsyn wou koppel (Beukes 2019a:66). Ook die heilshistoriese motief in die Hortus korrespondeer ineens met Hildegard se verstaan daarvan, naamlik'n radikale ommekeer van die sondeval: dat sowel die geestelike as die natuurlike werklikheid reeds in Christus verlos is en tot voleinding gebring sal word (Muessig 2000:88). Die werk is dus eksplisiet misties teologies. Die navorsingsvraag is egter hoe oor filosofie in die teks besin word en watter filosofiese bydraes in die teks geïsoleer kan word? Op die bywerkende spoor van, en in verruimende aansluiting by, 'n eerste poging in hierdie verband deur Joan Gibson (1989:85-98), meer as drie dekades gelede, word in hierdie artikel gepoog om sodanige filosofiese selfbesinning en sekondêre filosofiese bydraes in die Hortus uit te lig en te kommentarieer.

\section{Hortus deliciarum (ca. 1185) as 'n unieke mistieke kloosteruitset}

Daar bestaan geen ekwivalent vir Hortus deliciarum in die Middeleeuse literatuurgeskiedenis nie: Die werk is sedertdien in elke opsig sonder presedent en ongeëwenaard. So moeilik as wat dit is om die Hortus gevolglik binne 'n enkele genre te klassifiseer, hetsy as ' $n$ ensiklopedie (op regverdigbare aandrang van Muessig [2000:96]) in die tradisie nogeens van die Etymologiae van Isidorus (sien weer voetnoot 3), 'n estetiese soort summa of kunstige toevoeging tot Petrus Lombardus (1095-1160) se Sententiae in quatuor IV libris distinctae (op begryplike nadruk van Gibson 1989:87-88), konformeer die werk stilisties skerper aan 'n mistieke kloosteraanbod vanuit die 12de eeu as aan 'n ensiklopedie of 'n estetiese summa: Hoewel Herrada nie sistematies oor die geslotenheid van die kloosterlewe of die gedempte kloostermoraal van die laat 12de eeu besin het nie, kan die werk nie los bedink word van die kloosterwese as die institusionele ruimte waarin die manuskrip beslag gekry het nie (sien ook die uiteensetting van Griffiths se lesing van die Hortus infra).

Kloostermistiek was 'n spekulatiewe vorm van filosofie, waarin die mistieke (oorwegend negatiewe) teologieë van die Middeleeue in die tradisie vanaf Pseudo-Dionisius (ca. 500; Beukes 2018:1-3) feitlik sonder uitsondering opgeneem is. Kloostermistiek het ontwikkel vanuit die kontemplatiewe kloosterlewe en die asketiese dissiplines wat binne Middeleeuse kloosters bestendig en bevorder is (Leclerq 1982:191-235; McGinn 2012:2). Kloostermistiek was daarom gebaseer op ' $n$ meditatiewe benadering tot tekste, met 'n metode wat, anders as die skolastiese metode, nie afstandelik en objektief was nie, maar eerder as een van 'aktiewe deelname' beskryf sou moes word. ${ }^{4}$ Die Hortus voldoen volledig aan hierdie hermeneutiese opgaaf tot 'aktiewe deelname' met die meer as 'n duisend teksverwysings, wat midde honderde illustrasies en miniatuursketse op innoverende wyse in die manuskrip opgeneem is.

4.Vir toeganklike besprekings van kloosterteologie as sodanig, sien Beukes (2019a:66-69; 2020c:2) en Turner (2011:3-8). Kloostermistiek sluit per definisie (2019a:66-69, 2020c.2) en Turner (2011.3-8). Kloostermistiek sluit per definisie nie vanuit kloosterruimtes ontwikkel is nie, hoewel uitsonderinge voorgekom het, veral met verwysing na die opkoms van alternatiewe institusionele ruimtes soos dié veral met verwysing na die opkoms van alternatiewe institusionele ruimtes soos die
van die begyne in die laat 13 de en vroee 14 de eeue. Vir'n oorsig van die opkoms en ontwikkeling van die begynse ordes, sien Beukes (2019b:2-3). 
Die oorspronklike manuskrip (tesame met die slegs een behoue en volledige eksemplaar daarvan) is vernietig in die Frans-Pruisiese oorlog (1870) na die bombardering van Straatsburg in Augustus van daardie jaar (Bischoff 1979:18-19). Aangesien slegs onvolledige eksemplare van die manuskrip andersins wel behoue gebly het, word in die 1970's 'n omvangryke inisiatief van stapel gestuur om die Hortus so volledig moontlik te herkonstrueer. Met 19de-eeuse transkripsies van gedrukte weergawes van die onvolledige eksemplare as basis vir hierdie rekonstruksie van die vernietigde manuskrip, neem Rosalie Green, direkteur van die Index of Christian Art by Princeton Universiteit, die leiding met die herplasing van die meer as 1160 teksgedeeltes en vergelykende illustrasies, asook die katalogisering van die meer as 340 miniatuursketse en volblad-illustrasies. Green is bygestaan deur Michael Evans en Christine Bischoff, wat die teks krities geredigeer en georden het. Michael Curschmann het die 19deeeuse Duitse aantekeninge voor die vernietiging van die manuskrip, soos gedokumenteer deur C.M. Engelhardt, en aanvanklik geredigeer deur E. von Steinmeyer, opnuut geredigeer. In 1979 word dié manjifieke rekonstruksie van Hortus deliciarum in twee volumes deur Brill in Leiden as 'n projek van die Warburg Institute in Londen (met die projektitel Studies of the Warburg Institute XXXVI) gepubliseer: Die eerste volume bestryk die vier bogenoemde spesialiste en twee medewerkers se kommentaar op die manuskrip en verantwoording van die projek as sodanig (Green et al. 1979a). ${ }^{5}$ Die tweede volume bevat die keurig gerekonstrueerde manuskrip. ${ }^{6}$

Die aanvanklike resepsie van die oorspronklike manuskrip was beperk: Daar bestaan geen verwysings na die Hortus buite die kloosterkonteks van Hohenburg tot nadat die klooster (herbou en herstig in 1147) vier eeue later in 1546 in ' $n$ brand vernietig is nie. Die oorspronklike manuskrip is in daardie stadium vir die eerste keer buite die kloosterkonteks van Hohenburg in beskerming geneem (deur die bibliotekaris van die biskop van Straatsburg). Na talle omswerwinge is die manuskrip uiteindelik in 1803 in die Sentrale Register van Straatsburg geplaas en wyd aan die Middeleeuse literêre en kunshistoriese navorsingsgeselskap bekendgestel (Bischoff 1979:24-25). Dit was veral in die Duitse Forschung waar die Hortus vanaf 1803 tot 1870 grondig ontleed en

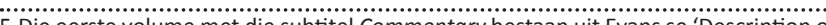
the manuscript and the reconstruction'; Green se 'The miniat ire en 'Le texte", Curschmann se 'The German glosses', asook medewerkers Kenneth Levy se 'The musical notation' en Julian Brown se 'The palaeography'. Verwysings na hierdie eerste volume word gedoen volgens Green et al. (1979a). Verwysings na die tweede volume, met die subtite Reconstruction, word gedoen volgens Herrada (1979) - sien dus ook Green et al. (1979b). 'n Gangbare eerste Engelse vertaling is egter twee jaar voor die publikasie van Green et al. se meesterprojek aangebied deur A. Caratzas (sien Herrada 1977).

6. Hierdie rekonstruksie in twee volumes van Hortus deliciarum (dus Green et al. [1979a] en Herrada [1979]) is skaars en buitengewoon duur. Slegs een tweedehandse eksemplaar in privaat besit was in November 2020 aanlyn te koop aangebied, teen meer as 4000 euro. Slegs enkele universiteitsbiblioteke in Nederland beskik oo gedrukte eksemplare van beide volumes. Ek was bevoorreg om die eksemplare van die Radboud Universiteitsbiblioteek in Nijmegen te kon gebruik. Ek kon egter nie kopieregklaring van die uitgewer bekom om eie fotografiese materiaal vanuit di betrokke eksemplare aan te bied nie en was daarom genoodsaak om Figuur 1 vanuit die openbare domein met hiperskakeling en lisensieerkenning (CC-BY-SA 3.0) te gebruik. Daar bestaan na my beste wete geen wettige digitale kopieë van die volledige werk nie. gekommentarieer is, soos byeengebring en herredigeer deur Curschmann (in Green et al. 1979a). Die teks was dus vanaf 1870 tot 1979 algeheel ondergekommentarieer en inligting daaromtrent was beperk tot hierdie Duitse kommentaartradisie. Die buitengewone waarde van Green en haar medewerkers se herkonstruksie van die vernietigde manuskrip (Green et al. 1979a) kan gevolglik nouliks oorbeklemtoon word.

Die oorspronklike manuskrip is tussen 1176 en 1184 byeengebring en rondom 1185 voltooi. Daar bestaan geen rekord van die materiële bronne waaruit Herrada se werk geput het nie. Gegewe die enorme omvang van die werk, is dit hoogs waarskynlik dat 'n hele aantal teksversorgers en kunstenaars onder Herrada se toesig aan die manuskrip gewerk het, maar dat minstens een vroulike kunstenaar en een manlike teksversorger heeltyds aan die projek gewerk het (Green \& Curschmann in Green et al. 1979a:25; 31). Daar bestaan ook geen duidelik beoogde adres vir die werk nie. Dit was in elk geval nie beperk tot die opvoeding en inlywing van nonne in die Augustynse klooster van Hohenburg nie, aangesien die hele godsdienstige gemeenskap in die openings- en afsluitingspassasies van die werk geïmpliseer word (Bischoff 1979:46). 'n Gebalanseerde standpunt is dat die materiële bronne van die werk waarskynlik altyd versluierd sal bly en dat Herrada wel die oogmerk gehad het om die manuskrip buite die klooster van Hohenburg te sirkuleer (Green in Green et al. 1979a:29). ${ }^{7}$

Die mees onlangse spesialisuitset wat die tekskritiese en hermeneutiese kwaliteit van Green en haar medewerkers se herkonstruksie van Hortus deliciarum in 1979 naastenby kon ewenaar, is Fiona J. Griffiths se The garden of delights: Reform and Renaissance for women in the twelfth century (2007; cf. Worm 2014:69-77). Die belangrikste bydrae van Griffiths se ontleding is dat sy die Hortus uitdruklik as 'n mistieke kloosterteks interpreteer: Sy posisioneer die Hortus naamlik binne die intellektuele konteks van die opkomende skolastiek en kloosterhervormings van die 12de eeu, met tweedelige klem op die bydraes van godsdienstige vroue in die dinamiese 12de-eeuse gesprek oor die behoud van die klooster as onderrigruimte (gegewe die opkoms van die universiteitswese in hierdie eeu) en die legitimiteit van manlike leierskap binne eksklusief vroulike onderrigkontekste. In teenstelling met ander didaktiese tekste wat in die 12de eeu oorwegend vir vroue aangebied is (soos Hildegard von Bingen se Scivias, Vitae meritorum en Divinorum operum; cf. Beukes 2019a:78-90), plaas die Hortus die klem op vroue se intellektuele (eerder as affektiewe) vermoëns en aanvaar vroue se deelname aan die tydgenootlike teologiese debatte as 'n onproblematiese gegewe (deur talle illustrasies in die Hortus beklemtoon

7.Green en haar medewerkers se herkonstruksie van die Hortus in 1979 is aan deeglike evaluasie in die Middeleeuse navorsingskonteks onderwerp. Vir twee kunshistoriese evaluasie in dic Niddeeuse navorsingskonteks onderwerp. Vir twee kunshistoriese resensies binne twee jaar van publikasie van die werk, sien Kaufmann (1981:172) en Kitzinger (1982:142-145). Vir 'n struktuuranalitiese verantwoording twee jaar na publikasie, sien Curschmann (1981:379-418). Sedertdien dien beide volumes van die rekonstruksie van die Hortus as die gestandaardiseerde bronteks in die spesialisnavorsing, soos gehandhaaf deur Gibson (1989), Griffiths (2006), Joyne (2016), Campbell (2015) en ook deur my (verwysende na Green et al. [1979a]) vir die eerste volume, en Herrada [1979] vir die tweede volume). 
waar vroue as fisies sterk en gespierd langs mans as ridders voorgestel word). Daarby fokus Griffiths (2007:221-223) op die Hortus se onderspeling van die 'gevare' aanwesig in vroulike seksualiteit en die gewaande bedreiging wat vroue vir (manlike) 'ampsuiwerheid' sou inhou: sy dui dit trouens as die mees merkwaardige kultuurhistoriese tendense in die Hortus aan (die teks benadruk na Griffiths se lesing naamlik eerder avarice of gierigheid as die kardinale sonde van die 12de eeu). Sy kom tot die gevolgtrekking dat Herrada se illustrasies en voorbeelde 'n nuwe model vir die bestudering van godsdienstige vroue in die $12 \mathrm{de}$ eeu noodsaak, een wat vroue se diep betrokkenheid in die intellektuele en geestelike strominge van hulle tyd erken (Griffiths 2007:223). Die algemene resepsie van Middeleeuse vroulike spiritualiteit as primêr affektief word met Herrada se klem op geslagtelike pariteit en die intellektuele bydraes van vroue in die 12 de eeu dus geproblematiseer. Daarom betoog Griffiths (2007:79-81, 164-166) dat lesings misplaas is wat op die Hortus fokus as 'n boek wat uitsluitlik oor vroue in die sentrale Middeleeue handel. Die werk handel oor sowél mans en vroue se opvoeding binne kloosterkontekste en gebruik 'n heilshistoriese struktuur waarin geslag ongeprioritiseerd is.

Twee ander onlangse en noemenswaardige spesialisuitsette, Danielle Joyner se Painting the Hortus deliciarum: Medieval women, wisdom and time (2016) en Nathaniel Campbell se "'Lest He should come unforeseen": The Antichrist cycle in the Hortus deliciarum' (2015), waardeer die Hortus in terme van estetiese en kunshistoriese oorwegings (Joyner) en teologiese aspekte, vernaamlik sentraal-Middeleeuse opvattinge rondom die bose en eskatologie (Campbell). Beide werke lewer binne hierdie twee diskursiewe kontekste sonderlinge en betekenisvolle bydraes. Nietemin word die kenmerkende afwesigheid van besprekings rondom die filosofiese aspekte in die Hortus ook in hierdie twee onlangse uitsette gehandhaaf. Kenmerkend aan die sekondêre literatuur oor die afgelope vier dekades, in sowel die kommentaar oor die herkonstruksie van die Hortus in Green et al. (1979a), die inleidingsnavorsing oor die afgelope drie dekades (soos uitgewys in voetnoot 1 ) en Griffiths se ontleding van 15 jaar gelede, is juis dat die filosofiese aspekte in die Hortus verbygegaan word. Hierdie versuim moet dus as ' $n$ onontginde ruimte in die navorsing aangedui word. Die filosofiese aspekte in die Hortus is natuurlik versluierd en word nie sistematies aangebied nie. Tog is dit moontlik om Herrada se filosofiese oriëntasie, voorkeurbronne en teoretiese posisie rondom kosmologie, etiek, epistemologie en psigologie tussen die reëls in die teks uit te lig. Die enigste poging waarvan ek bewus is wat hierdie filosofiese elemente in Herrada se werk oopdek, is Joan Gibson (1989) se kursoriese bespreking van die Hortus in die gevierde redaksiewerk van Mary Ellen Waithe ([ed.] 1989). In verruimende aansluiting by Gibson se reeds gedateerde lesing, word filosofiese selfbesinning en twee ander filosofiese aspekte in die Hortus vervolgens weer aangeroer.

\section{Besinning oor filosofie in Hortus deliciarum}

Gegewe die enorme uitsette van haar skolastieke medegangers in die 12de eeu volumegewys, moet Herrada se bydrae tot die filosofiese diskoers van die sentrale Middeleeue as beskeie getipeer word. Filosofiese selfbesinning in die Hortus bestryk, na my ontleding, effektief nie meer as sowat tien bladsye en een illustrasie in die werk nie (Herrada 1979:50-60; sien Figuur 1). Dit is juis die betreklike skraal aanbod van filosofie in vakkundige sin wat daartoe meewerk dat Herrada en die Hortus selfs nie eietyds in inleidingswerke tot Middeleeuse filosofie figureer nie (sien weer voetnoot 1). Die werk munt eerder teologies uit, veral ten opsigte van die heilshistoriese oriëntasie daarvan. Tog lewer Herrada wel 'n bydrae tot filosofiese selfbegrip en neem sy selfstandig deel aan die 12de-eeuse filosofiese gesprek, met die toegewing dat haar filosofiese bydrae in vakkundige $\sin$ beperk was.

Filosofiese selfbesinning - besinning oor filosofie, of filosofiese nadenke oor filosofie - lê reeds sedert Sokrates aan die hart van filosofie. Tog was daar 'n tendens in die Westerse ideëgeskiedenis om hierdie selfbesinning te verskerp gedurende periodes wanneer die legitimiteit en onafhanklikheid van filosofie onder druk gekom het. Die eerste helfte van die 12de eeu was ongetwyfeld so 'n periode. Met die toenemende aandrang in die konteks van die opkomende universiteitswese dat daar vakkundig tussen filosofie en teologie onderskei moes word ${ }^{8}$ (op aandrang van die eerste geslag universiteitskolastici, maar ook dialektiese filosowe soos Petrus Abelardus [1079-1142]), is die druk verhewig op filosofie om sigself vakkundig en in terme van die bestaande kurrikulum te verantwoord. Tot in die $12 \mathrm{de}$ eeu is filosofie enersyds tegnies verstaan, met verwysing na die bronne en inhoud van die sewe liberale lettere (die Alcuinse $^{9}$ trivium en quadrivium), en andersyds as die inhoud van geadministreerde geleerdheid, wat ' $n$ hermeneutiese, apologetiese en kategetiese voordeel vir die Christelike denkers vanuit die Latynse Weste ingehou het. Hoewel die laaste aspek in die 12de eeu gehandhaaf is, het die jong universiteite se dikwels arbitrêre wysigings aan die Alcuinse kurrikulum die eerste twee aspekte toenemend geproblematiseer. In die 12de eeu word intensiewe filosofiese selfbesinning daarom aangetref in die werke van, onder meer, Hugo van Saint-Viktor (1097-1141; vgl. Beukes 2020b:264-270), sy opvolger Richard van Saint-Viktor 8.Vir'n uiteensetting van die vroeg skolastiese onderskeid tussen filosofie en teologie, sien Beukes (2020a:l:439-446).

9 Alcuin (730-804) het in die agtste eeu die kurrikulum vir die intellektuele opvoeding van kerklui en kloosterlinge geformaliseer, wat tot nog hier in die vroeë 12 de eeu as die gestandaardiseerde kurrikulum vir opvoeding en onderrig gehandhaaf sou word. Afgesien van studies in die grondslae van die patristiek en die teoretiese aspekte van Bybelse eksegese, voer Alcuin vanuit Isidorus se Etymologiae die sewe liberale lettere in (die trivium [logika, grammatika en retoriek] en die quadrivium liberale lettere in (die trivium [logika, grammatika en retoriek] en die quadrivium [meetkunde, wiskunde, astronomie en musiek). Daarby voer hy Boethius se logika in, asook Boethius se kommentaar op Aristoteles se De interpretatione 9. Alcuin skryf ook direk temas uit Boethius se Consolatione voor: die vrae na noodwendigheid of determinisme, kans, vrye wil, die verhouding tussen universaliteit en partikulariteit, en die vraag na die hoogste goed. Herrada se diepe eerbied vi hierdie eeueoue onderrigmodel figureer konsekwent deur die Hortus, terwyl sy by die opkomende universiteitswese se talle wysigings aan die Alcuin-kurrikulum verbygaan. 
(d.1173), ${ }^{10}$ Alanus van Lille (d.1203; vgl. Beukes 2020a:I:529534) en Alexander van Hales (ca.1185-1245; vgl. Beukes 2020a:I:577-583). Herrada was diep bewus van hierdie selfbesinnende ontwikkeling en neem deel aan die groter 12de-eeuse projek om die legitimiteit van filosofie te verantwoord. Sy kies egter die konserwatiewe weg om met die handhawing van die Alcuinse kurrikulum die selfstandigheid en onafhanklikheid van filosofie te benadruk en filosofie nie dienstig aan teologie te stel of resloos in skolastiese teologie te laat opgaan nie.

\section{Herrada se filosofiese bronne en intellektuele oriëntasie}

Selfs net 'n oorhoofse lesing van Herrada se aanhaling van patristiese teksgedeeltes in die Hortus dui op die prominensie van Augustinus (354-430) in haar ideëwêreld, sowel vanuit Augustinus se oorspronklike tekste as vanuit sy mees prominente Middeleeuse eksegete, insluitende (Anicius Manlius Severinus) Boethius (ca. 477-524), Anselmus (10331109), die twee meer tydgenootlike 12de-eeuse filosofiese teoloë Hugo en Honorius Augustodunensis (ook 'Honorius van Autun' genoem, ca. 1080-1154), asook vermelde teoloog Lombardus. Herrada bied op geen plek die soort wydgaande filosofies-teologiese ontleding aan wat met die skolastiese metode geassosieer kan word nie. Sy bied wel aanhalings uit die werke van Augustinus en hierdie ander denkers aan, wat sy met die estetiese materiaal in die Hortus verweef. Sy werk dus nie self suiwer spekulatief of dialekties nie: Eerder sou haar styl as eklekties getipeer moet word, waarmee bedoel word dat Herrada slegs die gedeeltes vanuit hierdie filosofiese tekste kies wat die mistiek-estetiese aanbod in die Hortus didakties komplementeer. Anders gestel: Herrada se primêre filosofiese oriëntasie is meditatief en opvoedkundig eerder as spekulatief en skolasties.

Soos aangedui vanuit Griffiths (2007) se lesing, beteken hierdie meditatiewe benadering nie dat Herrada die voorkeur aan die (gewaande) vroulik-affektiewe op enige wyse bo die intellektuele prioritiseer nie. Sy hou haar digby haar filosofiese bronne, wat feitlik sonder uitsondering die vrug van die arbeid van monikke in die Augustynse, ChristelikPlatoniese tradisie was. Tog is dit duidelik dat Herrada voorbehoude gehad het oor die wyse waarop die opkomende universiteitswese besig was om filosofiese opvoeding in die 12de eeu te sekulariseer. Sy was deeglik op hoogte van die proto-humanistiese moment in hierdie ontwikkeling en staan afsydig daarteenoor: Trouens, die Hortus verraai 'n veel meer skeptiese houding jeens dié ontwikkeling as wat gangbaar in kloosterkringe self in die tyd aan die orde was. Sy haal gevolglik nie direk uit die antieke Griekse en Romeinse bronne aan nie. Sy verseg ook om die uitkomste van die

10.Richard van Saint-Viktor (of bloot St Viktor) was 'n Skot wat die klooster van Hugo by Saint-Viktor buite Parys waarskynlik betree het in die middel-1140's, na Hugo se afsterwe in 1141. Hy het onderhoof van die klooster rondom 1158 geword en hoofmonnik in 1162. Hy was Hugo se nougesette intellektuele opvolger, tot so ' $n$ mate dat sy gangbare monnikenaam St Victoris ontleen is aan die klooster: sy monnikenaam spreek boekdele van St Viktor se vermoë om Hugo se nalatenskap te bestendig en uit te bou. Hy neem Hugo se drie hermeneutiese sleutels vir Skrifhantering (letterlik ['histories'], allegories en tropologies) oor en bestendig dit in sistematiese Christelike wysheidsleer, waarin spekulatiewe filosofie steed noodsaaklik geag word, maar nou, eg $12 \mathrm{de}$-eeus, die onderskeid van teologie voortdurend en uitdruklik benadruk word; sien Beukes (2020a:I:489-493). rekurrikulering van die sewe liberale lettere, soos merkbaar in, onder meer, die innoverende voorstelle van haar vermelde tydgenoot Hugo (Beukes 2020b:268-270), in die Hortus te erken en gee eksplisiet voorkeur aan die gestandaardiseerde kurrikulum wat reeds in 789 deur Alcuin op die spoor van Boethius ontwikkel is (sien voetnoot 9 en Figuur 1).

Herrada was goed op hoogte met skolasties-teologiese ontwikkelinge in die 12de eeu, soos blyk uit die hoë frekwensie van aanhalings uit, en haar kommentaar oor, passasies in Lombardus se Sententiae in quatuor IV libris distinctae. Sy deel juis daarom nie in die antirasionalisme of minstens in die kritiek van filosofie in die werk van haar ouer tydgenoot, die Cistersensiër Bernardus van Clairvaux nie (vgl. Beukes 2020a:399-409). Soos haar Duitse tydgenoot Hildegard, sou Herrada eerder as 'n 'filosoof-teoloog' beskryf moes word, in die sin dat teologie sonder filosofie vir haar ondenkbaar was en dat sy die toenemende onderskeid tussen filosofie en teologie vanaf die vroeë 12de eeu nie onderskryf het nie (Beukes 2019a:73-78). Sy beskryf haar taak, synde dus 'filosoof-teoloog', as God se 'klein bytjie' wat 'onder Goddelike toesig' haar 'boek in soet heuning' verwerk het, vervaardig 'met nektar vanuit die verskillende blomme van die Heilige Skrif en filosofiese geskrifte' (Herrada 1979:4). Kinderlik soos wat dit miskien op die oog af kan aandoen, sluit die beeld van die by en heuningkoek aan by 'n diep gevestigde byekorfmotief in die vroeë Middeleeuse kloosterwese om die filosofiese arbeid van monnike te simboliseer (Gibson 1989:90). Die beeld dui daarom op sowel Herrada se sensitiwiteit vir haar filosofiese bronne, as die institusionele inbedding van die Hortus as 'n mistieke kloosterteks.

\section{Die nege Muses as sleutel tot filosofie selfbesinning in die Hortus}

Eie aan die sentraal-Middeleeuse taakstelling vir filosofie, bestryk die dissipline vir Herrada nie alleen 'n uitleg van en kommentaar op die tersaaklike oorlewering nie (in haar geval, Augustinus en die Augustynse tradisie), maar juis filosofiese selfbesinning: Wat is filosofie? Wat is die bronne van filosofie? Hoe behoort filosofie gebruik te word? Wat is die inhoud van filosofie? Hoe behoort filosofie onderrig te word en - wesenlik 12de-eeus - wat is die verhouding tussen teologie en filosofie? Herrada beantwoord dié selfbesinnende vrae oor filosofie in besonder deur middel van twee volbladillustrasies en miniatuursketse - wat die laaste vraag ineens implisiet beantwoord. Filosofie en teologie is volgens haar opvatting onlosmaaklik aan mekaar verbonde, maar moet wel van mekaar onderskei word (Herrada 1979:51). Sy gebruik gevolglik die aaneenskakeling van aanhalings aangaande en sketse van die nege Muses uit die Griekse mitologie, asook 'n allegorie van Boethius se Dame Filosofie in De consolatione philosophiae (sien Figuur 1), om kennisvorme in die $\mathrm{Ou}$ Testamentiese periode van mekaar te onderskei. Hierdie segment volg op haar kommentaar oor die sondvloed en gaan die gedeelte in die Hortus oor afgodediens in die $\mathrm{Ou}$ Testament vooraf. Herrada (1979:55-57) stel telkens dat filosofie 'menslike wysheid' na afloop van die sondvloed is 
en dat die mensheid, ná die verwarring by die toring van Babel, nie net demografies en taalkundig oor die aarde versprei is nie, maar inderdaad epistemologies in die war gebring is. Filosofie het daarom die taak om kennis te (her-) verwoord sodat dit oor taalkundige en epistemologiese grense heen kommunikeerbaar is (Gibson 1989:91).

Die kommunikasie tussen God en mens is deur die Babelse verwarring versteur, gedeeltelik herstel deur die Goddelike openbaring in die wet en die profete - maar uiteindelik eers volledig herstel deur die vleeswording van God in Christus. Die kommunikasie tussen mense onderling is egter onherroeplik by die toring van Babel onderbreek. Die belangrikste taak van filosofie en poësie (wat uitdruklik deur Herrada van mekaar geskei word en nie bloot onderskei word nie) is om begrip, verstaanbaarheid en opvoeding in die na-Babelse konteks te bevorder (Herrada 1979:51). Wanneer mense nie meer dieselfde 'taal' praat nie, voorsien filosofie 'n 'gemeenskaplike taal' waarin begrip en verstaanbaarheid 'n moontlikheid word. Outentieke filosofie (vir Herrada sluit dit die GrieksRomeinse bronne genuanseerd in) verteenwoordig die fatsoenlike gebruik van die rede en taal in antwoord op die drieledige Goddelike rede en Woord in die wet, die prediking van die profete (sy sluit die verkondiging van die apostels daarby in) en die vleesgeworde Woord, Christus.

Filosofiese vorm, genre en metode is vir Herrada duidelik van sekondêre belang: Primêr vir haar is die waarheidsgehalte van filosofie, wat sy toets aan die vermoë van filosofie om probleemoplossend, verduidelikend (of hermeneuties) en opvoedkundig (via die Alcuinse trivium en quadrivium) te wees. Die nege Muses word in nege aaneengeskakelde sketse voorgestel as die outentieke bronne van kennis waartoe filosofie wel toegang het: Herrada (1979:505) verwys daarby na die Muses as 'verteenwoordigend van die liberale lettere', wat nogeens op haar vertroue in die Alcuinse kurrikulum dui. Die tweeledige aantekeninge by die sketse van die Muses dui op die parallele proses in die verwerwing van kennis en die internalisering daarvan: Filosofiese kennis moet nie net verwerf word nie, maar moet die kennende subjek verander sodat hierdie 'veranderde subjek' ander subjekte filosofies kan opvoed of 'verander'.

Daarom dui Herrada (1979:54) aan die hand van die nege Muses nege 'stappe' in filosofiese besinning oor die werklikheid aan (na my sintese): (1) die verwerwing van kennis (by haar oorwegend Platonies-Augustyns en daarom deduktief); (2) toewyding om dit wat verwerf is te internaliseer en te aktualiseer; (3) 'n meditatiewe ingesteldheid ten opsigte van dit wat verwerf, geïnternaliseer en geaktualiseer is; (4) om vanuit die meditatiewe ingesteldheid tot' $n$ hermeneutiese verstaan te kom van wat verwerf is; (5) om vanuit die internalisering van dit wat verwerf is, in staat gestel te word om dit te onthou; (6) om vanuit die herinnering aan wat verwerf is, in staat gestel te word om dit te vergelyk met soortgelyke en verskillende vorme van kennis; (7) om vanuit die vergelyking van soortgelyke en verskillende vorme van kennis in staat te wees om dit te beoordeel; (8) om vanuit die beoordeling van soortgelyke en verskillende vorme van kennis, 'n kennisaanbod te kies; en (9) in staat te wees om die gekose kennisaanbod te verantwoord.

Hoewel Herrada dit nie deur 'n eksplisiete verwysing aandui nie, is dit duidelik dat die Augustynse drie-in-een-tese van die siel (korresponderend met die Drie-Eenheid) in hierdie stapgewyse ontplooiing werksaam is: (1) tot (4) dui op die fakulteit van die intellek; (5) en (6) dui op die fakulteit van die geheue; en (7) tot (9) dui op die fakulteit van die wil. Met hierdie Augustynse tese subtiel in die agtergrond, neem Herrada deel aan die kenmerkende 12de-eeuse psigologiese debat oor die fakulteite van die siel, wat verhewig sou word vanaf die eerste twee dekades in die 13de eeu met die herwinning van groot dele van die natuurfilosofiese Aristoteliese korpus in die Latynse Weste, insluitende Aristoteliese psigologie in De anima. Vir Herrada (1979:56) is die finale oogmerk van hierdie nege 'stappe' en gedempte Augustynse psigologie 'kennis van God'. Daarom dien die nege Muses, tot uitdrukking gebring in die nege 'stappe', nie primêr as inspirasie vir kuns en poësie nie (dit natuurlik ook), maar as filosofiese inspirasie: nie net om te ken nie, maar om te verstaan. Die nege Muses word konsekwent in die Hortus met sober, rasionele begrip geassosieer wat volg op kennis wat verwerf is deur die sewe liberale lettere. Maar daarby: die nege Muses dui op die innerlike, meditatiewe dissipline wat gekultiveer moet word ten einde die werklikheid filosofies te begryp.

\section{Dame Filosofie en die sewe allegoriese figure van die lettere}

Filosofie, allegories en sketsmatig aangebied as waarskynlik Dame Filosofie $^{11}$ vanuit Boethius (1998:38-59; Boek I) se De consolatione philosophiae, word selfbesinnend deur Herrada (1979:54:fol.32r) voorgestel binne 'n wysheidsimbool wat alle kennis toelig en voed deur middel van die sewe liberale lettere (sien Figuur 1). In hierdie volblad-illustrasie is Filosofie geposisioneer in die middel van 'n groot sirkelboog waarin die sewe tradisionele figure van die BoethiaansAlcuiniaanse kurrikulum eweredig naas mekaar geplaas is. Filosofie dra 'n drieledige kroon met inskripsies wat die Platoniese verdeling van filosofie in logika, etiek en fisika reflekteer. Filosofie hou ook 'n boekrol vas waarop gestel word dat 'alle wysheid van God kom' en dat 'slegs wyse mense vrye teuels aan hulle intuïsies mag gee' - 'n duidelike heenwysing na Plato se beroemde argument in die Gorgias, soos verwerk deur Boethius in Boek IV Afdeling II van die Consolatione (Boethius 1998:128). Die Goddelike oorsprong of herkoms van filosofie word benadruk deur 'n addisionele inskripsie wat stel dat die Heilige Gees 'die lettere ontwerp

11.Volgens Green (in Green et al. 1979a:103-107) moet dit nie as vanselfsprekend aanvaar word dat dit Boethius se Dame Filosofie is wat in die voorstelling aangebied word nie, aangesien die uitbeelding ook korrespondeer met ander ikonografiese voorstellings van 10 opsigte van wysheid en wysheidsliteratuur. Dit kan kunshistories sekerlik toegegee word - maar die uitbeelding en tekstuele plasings kunshistories sekerlik toegegee word - maar die uitbeelding en tekstuele plasings
in Figuur 1 maak 'n spontane historiese ideëkoppeling met Boethius se Dame Filosofie onafwendbaar. 


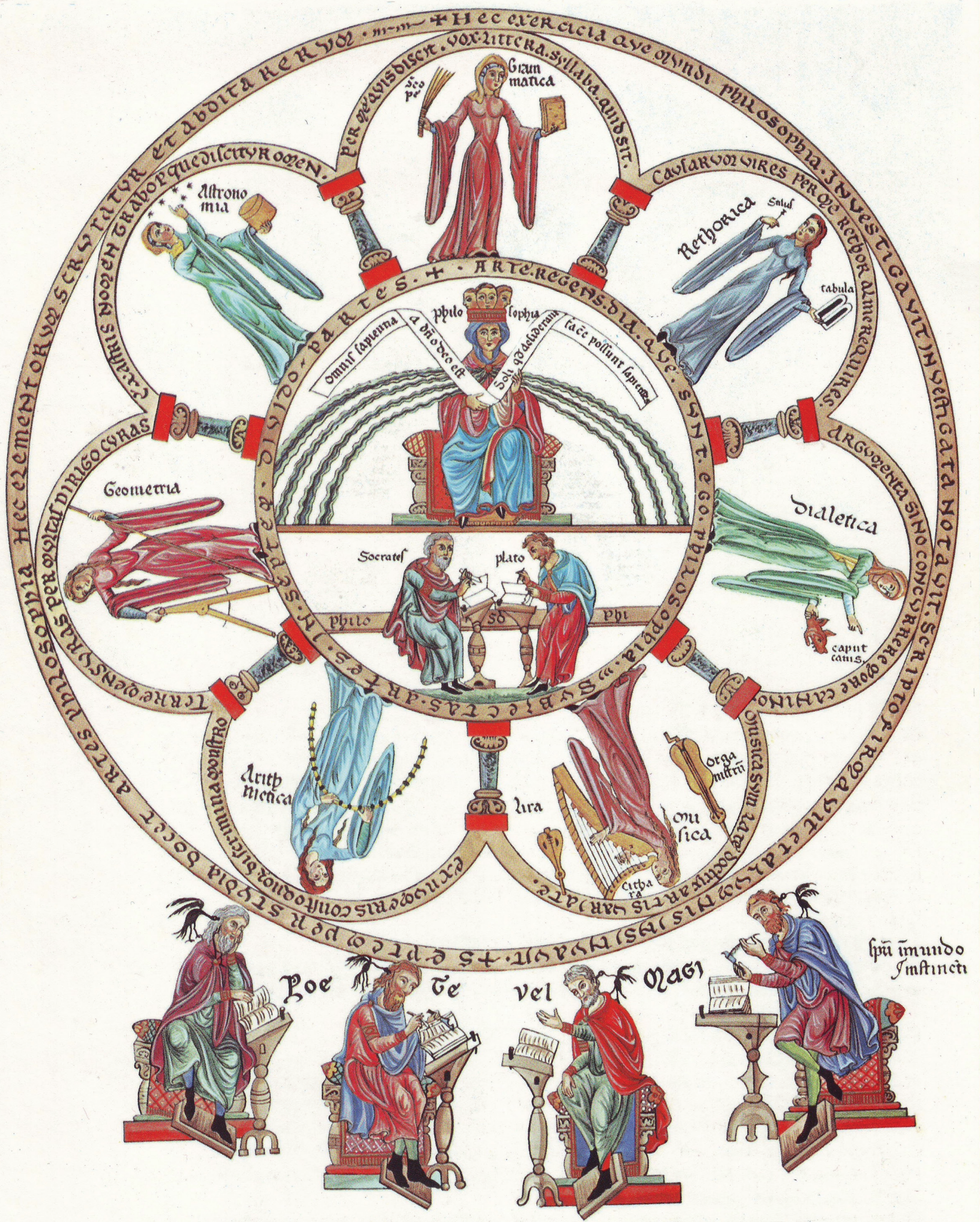

Bron: Wikimedia Commons, 2021, Philosophia et septem artes liberales, (CC-BY-SA 3.0), viewed 06 January 2021, from https://de.wikipedia.org/wiki/Benutzer:Dnalor_01 FIGUUR 1: Philosophia et septem artes liberales.

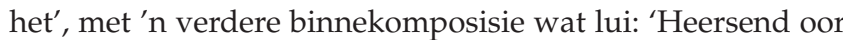
die lettere wat Goddelik geïnspireer is, verdeel ek, Filosofie, die vakgebied lettere in sewe dele' (Herrada 1979:57).
Uit haar bors vloei sewe strome water na die sewe allegoriese vroue wat die lettere verteenwoordig, geplaas binne 'n laaste sirkelinskrywing wat aandui dat die lettere die produk is van 
die sewe vroue se ondersoeke in Grieks-Romeinse filosofie, nougeset gedokumenteer en met trots aangebied aan hulle studente. Ses van die allegoriese figure (Grammatica, Rethorica, Arithmetica, Geometria, Astronomia en Musica) hou 'n pragmatiese instrument van haar betrokke dissipline vas (dus grammatika en retoriek vanuit die trivium en wiskunde, meetkunde, astronomie en musiek vanuit die quadrivium). Dit is slegs by die figuur Diale(c)tica (logika) waar simboliek 'n rol speel: Sy hou nie 'n instrument vas nie, maar die kop van 'n veglustige hond steek by haar mantelmou uit, met die inskripsie daarby (vry vertaal): '(Ek laat my argumente) soos honde aanval' (oor die eieaardigheid van die instrumente van die ander ses figure, sien Green in Green et al. 1979a:104-106; vgl. Gibson 1989:93).

\section{Plato, Sokrates, die twee digters en die twee magi: Herrada se besinning oor filosofiese opvoeding}

Herrada (1979:52-56) se besinning oor die aard, inhoud en oogmerke van filosofie word verdiep in dieselfde illustrasie met kommentaar (steeds Figuur 1) waarin Sokrates en Plato steeds binne die allegoriese sirkel van die lettere, direk onder die troon van Filosofie, sit en skryf. Herrada (1979:57) se inskripsie hierby dui aan dat die leerstellinge van die antieke filosowe verdeel behoort te word in etiek, fisika (of in Aristoteliese terme, natuurlike filosofie) en retoriek. Die antieke filosowe word sonder apologie aangedui as 'die wyses van die wêreld' en 'die geleerdes van die nasies'.

Die onderste deel van die illustrasie (Figuur 1), maar nou buite die allegoriese sirkel van die lettere, word ingeneem deur vier anonieme figure, (van links na regs) twee digters en twee magi, elkeen by die oor geïnspireer deur 'n influisterende, makabere swart voël. Die inskripsie tussen die twee middelste figure en Herrada (1979:56) se meegaande teks beeld hierdie vier figure uit as die skeppers van die fabels van valse gode. Hierdie vier figure beskik wel oor kennis, maar dit is kennis sonder sanksie - juis omdat dit nie vanuit die sewe lettere, wat Goddelik geïnspireerd geag word, ontgin is nie. Die sewe lettere, synde die voedingsbron van 'n Goddelik geïnspireerde kennis wat tot beskikking van sowel Christen as heiden is, speel geen rol in hierdie (vir Herrada) verdagte vorm van kennisverwerwing nie.

Teenoor die polemisering van die kennis buite die lettere van die twee digters en die twee magi, word filosofie herhaaldelik (Herrada 1979:52-57) beskryf as die 'verantwoorde ondersoek na die natuur' en die 'liefde vir verantwoorde wysheid', terwyl 'filosowe' eenvoudig beskryf word as 'almal wat haar (Filosofie) liefhet'. Herrada (1979:54) gebruik hierdie elementêre definisie van filosofie en filosowe, met klem op haar indruk van die 'verantwoording' van die ordelike oordrag van filosofiese kennis. Daar moet sistematiese ontwikkeling in filosofiese onderrig en die verwerwing van filosofiese kennis wees. Die ordelike en sistematiese kwaliteit van filosofiese opvoeding word nogeens aan die sewe liberale lettere getoets: dit word 'liberaal' genoem omdat dit die student van 'n gebondenheid aan die aardse bevry en vrystel tot kennisverwerwing aangaande God en dit wat God die mens bied in terme van die vermoëns van die fakulteite van die siel (intellek, geheue en wil), soos wat dit neerslag vind in die sewe lettere. Die afstanddoening van die wêreldse en die gevolglike vryheidstelling tot outentieke of liberale kennis staan sentraal in die Hortus: Die werk begin en eindig met gedigte wat afstandname van die wêreld betoog, en vir Herrada speel filosofie en die sewe lettere in hierdie bevryding van die mundane ' $n$ wesenlike en deurslaggewende rol.

\section{Beskeie filosofiese deelname vanuit die Hortus deliciarum}

Vanuit die besinning oor filosofie in die Hortus neem Herrada beskeie, maar selfstandig deel aan die filosofiese diskoers van die 12de eeu, wat vyfledig gerubriseer kan word in kosmologie, epistemologie, metafisika, psigologie en etiek (hoewel die Platonies-gedrewe metafisika van die 12de eeu binne die eerste dekades van die 13de eeu dramaties sou verander deur die beskikbaarstelling van 'n substansiële deel van die oorleefde Aristoteliese korpus in Latyn).

Kosmologie (of skeppingsleer, in teologiese taal), lê aan die hart van kloosterteologie in die vroeë en sentrale Middeleeue (Beukes 2020c:2-3). In die 12de eeu vind daar egter toenemend 'n vermenging plaas tussen die Joods-Christelike weergawe van die ontstaan van die wêreld, heidens-filosofiese kosmologie en tydgenootlike wetenskaplike bevindinge. Ook die Hortus reflekteer hierdie vermenging: Herrada (1979:24, 292, 364) bied byvoorbeeld 'n illustrasie met 12deeeuse wetenskaplike kommentaar aan oor die Hellenistiese aksent op die natuurlike elemente van lug en water en vergelyk daarvandaan die liggaam van Christus met 'n kristal. Ofskoon hiermee 'n oënskynlik humanistiese oriëntasie verraai word, bed Herrada die jukstaposisie van Hellenistiese en Joods-Christelike elemente telkens binne uitdruklik godsdienstige raamwerke. Die mens wat as mikrokosmos voorgestel word, is hiervan die mees prominente voorbeeld (Herrada 1979:28-30, 438-440). Soos vir haar Duitse medeganger Hildegard (Beukes 2019a:67), neem die mens vir Herrada ' $n$ belangrike filosofiese plek in die skepping in: Elke mens is geskep na die beeld van God as 'n enkele, onherleibare en onherhaalbare individu, met drie eienskappe, wat self weer uniek in elke partikuliere individu tot uitdrukking gebring word: liggaam, siel en intellek. Die mens is in hierdie sin ' $n$ 'mikrokosmos' omdat selfs die kleinste deel van die menslike liggaam een of ander aspek in die natuur, in die etiek, in die buiteliggaamlike en selfs die bonatuurlike simboliseer. Die mens staan daarom sentraal in die siklusse en seisoene van die skepping. Die mens verteenwoordig die konstante beweging vanaf die universeel abstrakte na die partikulier konkrete (Herrada 1979:453). Daarom kwalifiseer Herrada die skepping met spesifieke verwysing na die individuele en gemeenskapgebonde mens (veral ten opsigte van die kerk as gemeenskap van gelowiges) as sentraal daarin. Anders gestel: sonder die mens as 
middelpuntvliedende krag en teenwoordigheid in die skepping, sou die skepping niks meer as 'n abstraksie gewees het nie. Die mens as allegoriese mikrokosmos bring kontinuïteit tussen die menslike en die Goddelike tot stand in terme waarvan geskiedenis juis as heilsgeskiedenis gekenteken kan word (Herrada 1979:506).

Aangesien die Alcuinse kurrikulum die plek van etiek binne die sewe liberale nie uitdruklik aanwys nie, maak Herrada (1979:53) die Platoniese keuse om etiek uitdruklik binne die trivium (dus binne die konteks van logika, grammatika en retoriek) te rubriseer. Etiek hang dus vir haar saam met die logiese faset van filosofie, soos geformuleer deur Aristoteles, terwyl die quadrivium (wiskunde, meetkunde, astronomie en musiek) voortkom uit fisika en natuurlike filosofie, soos geformuleer deur Pythagoras (Herrada 1979:52). Die primêre opgaaf van logika (na die allegoriese figuur Diale[c]tica; sien Figuur 1) is om waar en vals van mekaar te onderskei. Herrada (1979:53) gee natuurlik toe dat etiek nie eksplisiet aan enige van die sewe lettere gekoppel is nie, maar verstaan etiek op Sokraties-Platoniese wyse as die onderskeid tussen goed (waar) en kwaad (vals), waaruit die Sokratiese deugde van wysheid, sin vir geregtigheid, ewewigtige temperament en innerlike krag voortkom.

Herrada (1979:53-54) volg dié Hellenistiese onderskeid op met 'n verdere onderskeid, naamlik tussen die praktiesspekulatiewe en die aktief-kontemplatiewe lewe. Etiek beteken dus om die goeie kontemplatief, sowel as spekulatief te onderskei: Dit is deur die goeie te kan onderskei deur doelgerig besinnende en aktiewe kontemplatiewe inoefening dat die menslike gees tot die absolute Goed (God) verhef word, maar tegelyk is dit ook deur spekulatiewe onderskeid van die goeie in die konkrete praktyk van die alledaagse lewe dat etiek gestalte kry. Die goeie moet sowel bedink as beoefen word. Die 'korrekte ordening van die innerlike lewe' (Herrada 1979:326) is afhanklik van die dinamika tussen die kontemplatiewe en spekulatiewe. Morele handeling kan nie los bedink word van die verstaan daarvan nie, net so min soos wat die kontemplatiewe verstaan van die goeie op sigself geld.

\section{Samevatting en konklusie}

Herrada Landsbergensis het 'n konserwatiewe, dog betekenisvolle bydrae tot selfbesinning in filosofie in die tweede helfte van die 12de eeu gelewer. Vanuit 'n PlatoniesAugustynse raamwerk het haar Hortus deliciarum, wat hier uitdruklik as 'n mistieke kloosterteks met die hermeneutiese gerigtheid van 'aktiewe deelname' gelees en hanteer is, op unieke estetiese wyse die waarde en volgehoue toepaslikheid van die Alcuinse kurrikulum binne die konteks van die opkomende universiteitskolastiek en die nuwe universiteitskurrikula van die 12 de eeu bevestig. Deur haar didaktiese besinning oor filosofie deur middel van die 'nege Muses', 'Dame Filosofie en die sewe allegoriese figure van die liberale lettere' en 'Plato, Sokrates, die twee digters en die twee magi' as toegangspunte te gebruik en haar beskeie kosmologiese ('die mens as mikrokosmos') en etiese ('om die goeie kontemplatief sowel as spekulatief te onderskei') bydrae tot die 12de-eeuse filosofiese diskoers daarby in te reken, kon hier aangedui word dat die Hortus se aanspraak nie beperk was tot ' $n$ estetiese en heilshistoriese betoog nie. Sodanig ontsluit, kan die Hortus ook as 'n filosofies-didaktiese teks in eie reg beskou word. Dit is dus nie net die kunshistoriese en teologiese belang van die Hortus wat eietyds die aandag verdien nie. Juis die selfbesinnende en ander filosofiese aspekte in die werk kan as 'n unieke intellektuele aanbod vanuit die sentrale Middeleeue tot die groter landskap van die Westerse ideëgeskiedenis beskryf word. Daarvoor verdien die stylvolle abdis filosofie se diepste agting.

\section{Erkenning}

Die skrywer is verbonde aan die Sentrum vir die Geskiedenis van Filosofie en Wetenskap (CHPS), Fakulteit Filosofie, Teologie en Religiewetenskappe, Radboud Universiteit Nijmegen, Nederland.

\section{Mededingende belange}

Die skrywer verklaar dat hy geen finansiële of persoonlike verbintenis het met enige party wat hom nadelig kon beïnvloed in die skryf van hierdie artikel nie.

\section{Outeursbydrae}

J.B. was die enigste outeur betrokke by die skryf van die artikel.

\section{Etiese oorwegings}

Die artikel volg alle etiese standaarde vir navorsing sonder direkte kontak met mens of dier.

\section{Befondsing}

Hierdie artikel is befonds deur die Departement Filosofie \& Klassieke, Fakulteit Geesteswetenskappe, Universiteit van die Vrystaat.

\section{Data beskikbaarheidsverklaring}

Datadeling is nie van toepassing op die artikel nie, aangesien geen nuwe data in hierdie studie geskep of ontleed is nie.

\section{Vrywaring}

Die sienings en menings wat in die artikel uitgedruk word, is dié van die skrywer en weerspieël nie noodwendig die amptelike beleid of posisie van enige geaffilieerde agentskap van die skrywer nie.

\section{Bronnelys}

Barney, S.A., Lewis, W.J., Beach, J.A., Berghof, O. \& Hall, M., 2006, The Etymologies of Isidore of Seville, Cambridge University Press, Cambridge.

Beukes, J., 2018, "n Herlesing van Pseudo-Dionisius se metafisika', HTS Teologiese Studies/Theological Studies 74(4), Art. \#5111, 1-9. https://doi.org/10.4102/hts. v74i4.5111 
Beukes, J., 2019a, 'Hildegard von Bingen as 'n 12de-eeuse filosoof-teoloog', Litnet Akademies 16(1), 64-102, viewed 06 January 2021, from https://www.litnet. co.za/wp-content/uploads/2019/06/LitNet_Akademies_16-1_Beukes 64-102. po.za/w

Beukes J., 2019b, “'Maak die wêreld nie tot bespotting nie”: 'n Herwaardering van die filosofiese aspekte in Mechtild von Magdeburg se Das fließende Licht der Gottheit (1250)', Verbum et Ecclesia 40(1), Art. \#1965, 1-8. https://doi.org/10.4102/ ve.v40i1.1965

Beukes, J., 2020a, Middeleeuse filosofie, vols. I \& II, Akademia, Pretoria.

Beukes, J., 2020b, 'Omnium expetendorum prima est sapientia: Hugo van SaintViktor (1097-1141) en die probleem van hiperspesialisasie in die eietydse wetenskapsbegrip', Litnet Akademies 17(1), 262-297, viewed 06 January 2021, from https://www.litnet.co.za/wp-content/uploads/2020/04/LitNet_Akademies_17-1_ Beukes_262-297.pdf

Beukes, J., 2020c, 'Juliana van Norwich (1342-ca.1416) as post-skolastiese teoloog', HTS Teologiese Studies/Theological Studies 76(4), Art. \#6001, 1-11. https://doi. org/10.4102/hts.v76i4.6001

Bischoff, C., 1979, 'L'Histoire', in R. Green, M. Evans, C. Bischoff \& M. Curschmann (eds.), Hortus deliciarum of Herrad of Hohenbourg, Volume I, Commentary, pp. 1-88, Brill, Leiden.

Boethius, 1998, De consolatione philosophiae (Boethius' The consolation of philosophy), (intro. \& transl.), V.E. Watts, The Folio Society, London.

Bosley, R.N. \& Tweedale, M. (eds.), 2004, Basic issues in Medieval philosophy. Selected readings presenting the interactive discourses among the major figures, readings presenting the
Broadview Press, Ontario.

Brown, S.F. \& Flores, J.C., 2007, Historical dictionary of Medieval philosophy and theology, The Scarecrow Press, Plymouth.

Campbell, N., 2015, “'Lest He should come unforeseen": The Antichrist cycle in the Hortus deliciarum', Gesta 54(1), 85-118. https://doi.org/10.1086/679399

Copleston, F.C., 1993, A history of philosophy, Volume II, Medieval philosophy, Doubleday, New York, NY.

Curschmann, M., 1981, 'Texte - Bilder - Strukturen: Der "Hortus deliciarum" und die frühmittelhochdeutsche Geistlichendichtung', Deutsche Vierteljahrschrift für Literaturwissenschaft und Geistesgeschichte 55(3), 379-418. https://doi. org/10.1007/BF03375067

Eckenstein, L., 2010, Woman under monasticism: Chapters on Saint-Lore and convent life between A.D. 500 and A.D. 1500, Theophania, Calgary.

Gibson, J., 1989, 'Herrad of Hohenbourg', in M.E. Waithe (ed.), A history of women philosophers, Volume II, Medieval, Renaissance and Enlightenment women philosophers, pp. 85-98, Kluwer, Dordrecht.

Gracia, J.J.E. \& Noone, T.B. (eds.), 2006, A companion to philosophy in the Middle Ages, Blackwell, Oxford.

Grant, E., 2004, God and reason in the Middle Ages, Cambridge University Press, Cambridge.

Green, R., Evans, M., Bischoff, C. \& Curschmann, M. (eds.), 1979a, Hortus deliciarum of Herrad of Hohenbourg, Volume I, Commentary, Brill, Leiden.

Green, R., Evans, M., Bischoff, C. \& Curschmann, M. (eds.), 1979b, Hortus Deliciarum of Herrad of Hohenbourg, Volume II, Reconstruction, Brill, Leiden (see Herrada 1979).

Griffiths, F., 2007, The Garden of delights: Reform and Renaissance for women in the twelfth century, The Pennsylvania State University Press, University Park, PA.

Hannam, J., 2009, God's philosophers: How the Medieval world laid the foundations of modern science, Icon Books, London.

Herrada (Landsbergensis), 1977, Hortus deliciarum (Garden of delights), Caratzas, A. (transl.), Caratzas Publishers, New York, NY.
Herrada (Landsbergensis), 1979, Hortus deliciarum of Herrad of Hohenbourg, Volume II, Reconstruction, R. Green, M. Evans, C. Bischoff \& M. Curschmann (eds.), Brill, Leiden.
Leideonsti

Hyman, A., Walsh, J.J. \& Williams, T. (eds.), 2010, Philosophy in the Middle Ages: The Christian, Islamic and Jewish traditions, Hackett, Indianapolis, IN.

Joyner, D., 2016, Painting the Hortus deliciarum: Medieval women, wisdom and time, The Pennsylvania State University Press, University Park, PA.

Kaufmann, C.M., 1981, 'Review: Herrad of Hohenbourg, Hortus deliciarum by Rosalie Green, Michael Evans, Christine Bischoff, Michael Curschmann, T. Julian Brown, Kenneth Levy', The Burlington Magazine 123(936), 172.

Kenny, A., 2005, Medieval philosophy, Clarendon Press, Oxford.

Kitzinger, E., 1982, 'Review: Herrad of Hohenbourg, Hortus deliciarum by Rosalie Green, Michael Evans, Christine Bischoff, Michael Curschmann', The Art Bulletin 64(1), 142-145. https://doi.org/10.2307/3050204

Koterski, J.W., 2009, An introduction to Medieval philosophy: Basic concepts, WileyBlackwell, Sussex.

Kretzmann, N., Kenny, A. \& Pinborg, J. (eds.), 1982, The Cambridge history of Later Medieval philosophy, Cambridge University Press, Cambridge.

Lagerlund, H. (ed.), 2011, Encyclopedia of Medieval philosophy: Philosophy between 500 and 1500, Springer, London.

Leclerq, J., 1982, The love of learning and the desire for God: A study of monastic culture, Fordham University Press, New York, NY.

Luscombe, D.E., 1997, Medieval thought, Opus-Oxford University Press, Oxford.

Marenbon, J., 1991, Later Medieval philosophy (1150-1350): An introduction, Routledge, London.

Marenbon, J. (ed.), 1998, Medieval philosophy, Routledge History of Philosophy Volume III, Routledge, London.

Marenbon, J., 2007, Medieval philosophy: An historical and philosophical introduction, Routledge, London.

Martin, C.J.F., 1996, An introduction to Medieval philosophy, Edinburgh University Press, Edinburgh.

McGinn, B., 2012, The varieties of vernacular mysticism, 1350-1550, Crossroad, New York, NY.

McGrade, A.S. (ed.), 2003, The Cambridge companion to Medieval philosophy, Cambridge University Press, Cambridge.

Muessig, C., 2000, 'Learning and mentoring in the twelfth century: Hildegard of Bingen and Herrad of Landsberg', in G. Ferzoco \& C. Muessig (eds.), Medieval monastic education, pp. 87-104, Leicester University Press, London.

Pasnau, R. \& Van Dyke, C. (eds.), 2010a, The Cambridge history of Medieval philosophy, Volume I, Cambridge University Press, Cambridge.

Pasnau, R. \& Van Dyke, C. (eds.), 2010b, The Cambridge history of Medieval philosophy, Volume II, Cambridge University Press, Cambridge.

Turner, D., 2011, Julian of Norwich, theologian, Yale University Press, New Haven, CT.

Waithe, M.E. (ed.), 1989, A history of women philosophers, Volume II, Medieval, Renaissance and Enlightenment women philosophers, Kluwer, Dordrecht.

Wikimedia Commons, 2021, Philosophia et septem artes liberales, (CC-BY-SA 3.0), viewed 06 January 2021, from https://de.wikipedia.org/wiki/Benutzer:Dnalor_01

Worm, A., 2014, "'You shall all live together in harmony and spiritual unity": Images of abbesses and female religious communities in the Empire', in V. Fraeters \& I. De
Gier (eds.), Mulieres religiosae: Shaping female spiritual authority in the Medieval and early modern periods, pp. 37-85, Brepols, Turnhout. 